\title{
REAKTUALISASI KHASANAH KEWIRAUSAHAAN PERSPEKTIF TIONGHOA MUSLIM
}

\author{
Moh Syakur ${ }^{1}$, Muhammad Faiq ${ }^{2}$ \\ ${ }^{1}$ Fakultas Ushuluddin dan Humaniora UIN Walisongo Semarang \\ ${ }^{2}$ Fakultas Ushuluddin dan Humaniora UIN Walisongo Semarang \\ moh.syakur@walisongo.ac.id \\ faiq_muhammad@walisongo.ac.id
}

\begin{abstract}
In the global economy, ethnic Chinese entrepreneurship strategy is one of the concepts of a mature economy. In fact, china is now one of the largest economic powers in the World. No wonder indonesia has a direct influence on the economic impact of China. One of the effects is that the majority of indonesia's growing economy is controlled by ethnic Chinese. Therefore, it is necessary to look at the entrepreneurial benefits carried out by ethnic Chinese who convert to Islam.
\end{abstract}

Keywords: Entrepreneurship, Chinese, Islam

\begin{abstract}
Abstrak
Dalam ekonomi global, strategi kewirausahaan etnis Tionghoa merupakan salah satu konsep perekonomian yang sudah matang. Bahkan, kini negara China merupakan salah satu kekuatan ekonomi terbesar di Dunia. Tak heran jika negara Indonesia mendapat pengaruh secara langsung dampak perekonomian dari China. Salah satu dampaknya adalah mayoritas perekonomian yang berkembang di Indonesia dikuasai oleh etnis Tionghoa. Untuk itu, perlu kiranya melihat khasanah kewirausahaan yang dilakukan oleh etnis Tionghoa yang memeluk agama Islam.
\end{abstract}

Kata kunci: Kewirausahaan, Tionghoa, Islam

\section{A. PENDAHULUAN}

Negara China sekarang bisa dinobatkan menjadi salah satu Negara maju dan berkembangdi Dunia. Kekuasaan perekonomiannya semakin melesat tajam mengancam Negara-negara maju yang lainnya. Terlebih setelah diberlakukannya perdagangan bebas dunia (ACFTA). Banyak produk-produk pasaran yang bersal dari Negara tirai bambu tersebut. 
Selain di bidang perekonomian, Negara China juga memiliki peran penyebaran kependudukan yang merata di setiap Negara, tak terkecuali di Indonesia sendiri

Menurut catatan literatur sejarah Tiongkok, hubungan Indonesia dengan Negara China sudah ditandai dengan perniagaan. Berbagi macam bahan komoditi dibawa ke samudra Hindia oleh armada Cheng Ho; antara lain berbagi kain sutra, sulaman, porselen, jebat, emas, teh, beras, kedelai, jeruk, kapur barus, buku dan lain-lain ${ }^{1}$. Hal ini membuktikan bahwa Negara China memiliki semangat tinggi untuk melakukan wirausaha demi melangsungkan kehidupan yang lebih baik.

Jika membahas masalah perekonomian dunia kekinian tak lepas dengan isu neoliberal dan kapitalis. Kedua kaum itulah yang memiliki kendali untuk menguasai perekonomian dunia. Kapitalis dan neoliberal banyak dijumpai di daerah Barat yaitu Amerika dan Negara Eropa. Sedangkan di kawasan Asia masih sangat lemah untuk menjadi pelaku usaha dan pelaku bisnis dunia.

Negara Indonesia pernah mengalami krisis moneter, hal ini dikarenakan menurunnya perekonomian Negara. Salah satu faktor penyebab merosotnya perekonomian Negara adalah sedikitnya jumlah wirausaha yang masih tetap berjalan. Sehingga untuk mencari solusi dari dekadensi perekonomian Indonesia pelu mengangkat isu kewirausahaan. Hal ini merupakan kebutuhan mutlak yang harus diwujudkan. Percetakan wirausaha baru akan mengatasi rendahnya penciptaan lapangan kerja. Isu wirausaha banyak diangkat karena kawasan Asia Pasifik khususnya Indonesia mengalami kekurangan unit usaha apabila dibandingkan dengan besarnya kebutuhan ekonomi dan penduduk di

\footnotetext{
${ }^{1}$ Yuanzhi Kong, Cheng ho; Muslim Tionghoa, (Jakarta: Yayasan Pustaka Obar Indonesia, 2011), hlm. 219.
} 
kawasan ini. Dengan cara melahirkan wirausaha baru maka kebutuhan akan unit usaha baru dalam jumlah besar dapat terpenuhi.

Akan tetapi, tentu saja melahirkan wirausaha baru tidaklah sederhana, lebih mudah diucapkan daripada dilaksanakan. Terlebih apabila wirausaha baru yang ingin diciptakan berada di luar sektor pertanian sehingga memerlukan persiapan dari segi pendidikan, sumber daya manusia serta pembiayaan yang sering menjadi masalah. Wirausaha baru memang bisa lahir dengan sendirinya, tetapi jumlahnya sangat kecil. Perlu ada penanganan terpadu sehingga menghasilkan wirausaha yang berkualitas dan signifikan terhadap jumlah penduduk di Indonesia.

Kunci kebangkitan bangsa dapat diketahui melalui kewirausahaan yang dimilikinya. Kebangkitan suatu bangsa terutama Indonesia harus lebih mendahulukan kepentingan peningkatan wirausaha. Jumlah wirausaha di Indonesia masih tergolong rendah jika dibandingkan dengan Negara-negara maju. Amerika serikat, Eropa barat, kewirausahaan menjadi kekuatan ekonomi Negara tertentu, sehingga Negara-negara tersebut menjadi kekuatan ekonomi dunia.

Banyak manfaat yang didapatkan dari berwirausaha ketimbang menghandalkan pegawai atau buruh. Wirausahawan akan menjadi kelas tersendiri di tengah masyarakat dan dianggap memiliki wibawa tertentu lebih disegani dan dihormati ${ }^{2}$. Berkaca dari teori keuntungan kewirausahaan tersebut, jikalau Negara Indonesia ingin lebih disegani seharusnya lebih bisa menjadi Negara yang produktif dan mengimplementasikan pendidikan berbasis kewirausahaan.

Ketika memberikan sambutan saat berkunjung pondok pesantren, Presiden Jokowi menekankan pentingnya jiwa kewirausahaan, inovasi

\footnotetext{
${ }^{2}$ Kasmir, Kewirausahaan, (Jakarta: PT Raja Grafindo Persada, 2009), hlm. 6.
} 
teknologi, dan kreativitas. Ketiga aspek itu sebetulnya tercakup dalam nebula (megabudaya) China yang ironisnya tidak boleh diajarkan semasa Orde Baru. Dalam pelajaran sejarah di sekolah diajarkan pengaruh nebula yang berasal dari India, Arab, dan Eropa, tetapi tidak demikian halnya dengan sumbangan nebula China bagi peradaban Nusantara. Diskriminasi sejarah itu berlangsung sejak peristiwa G30S tahun 1965. Pemerintah melarang segala sesuatu yang berbau China sampai muncul adanya Reformasi tahun 1998.

Kehidupan kita sehari-hari bisa berjalan dan berkembang seperti sekarang ini antara lain berkat ilmu dan teknologi yang berasal dari kebudayaan China. Orang Belanda yang berada di Jawa mulanya kurang memerhatikan pertanian. Orang Tionghoa-lah yang mengembangkan budi daya padi. Setiap tahun banyak jung (kapal besar dari kayu) datang ke sini untuk berdagang sambil membawa 1000-an orang China untuk dipekerjakan, terutama di lahan pertanian. Kebudayaan Negara China memiliki nilai-nilai pendidikan yang kental. Mereka memiliki kepercayaan bahwa pendidikan, ritual, prinsip-prinsip moral adalah cara penyelesaian yang dapat mengubah manusia jahat menjadi manusia baik. $^{3}$

Kini keberadaan etnis Tionghoa semakin diakui dengan SDM yang dimilikinya. Terlebih Sejak era kepemimpinan Gus Dur (Abdurrohman Wahid) berkuasa, agama Konghucu yang menjadi pegangan hidup etnis Tionghoa mulai diakui oleh pemerintah, dan saat itu pula pemerintah menghadiri perayaan imlek secara resmi pada tahun 2000 (Leo Suryadhinata: $2012: 95)^{4}$.

\footnotetext{
${ }^{3}$ Tan Ta Sen, Cheng Ho, Penyebar Islam dari China ke Nusantara, (Jakarta: Kompas, 2010), hlm. 51. 95.

${ }^{4}$ Leo Suryadhinata:Prominant Indonesian Chinese; (Jakarta: Gramedia, 2012), hlm.
} 
Maka dengan hal ini, kiranya pandangan kaum marjinal nampak sudah tidak cocok lagi dengan etnis Tionghoa di Indonesia saat ini. Secara bukti konkret, mereka sudah menunjukkan kepiawaiannya dalam kewirausahaan. Kemampuan untuk memanage, mengatur dan menjalankan roda usaha perlu diapresiasi oleh pemerintah dan masyarakat, Guna kepentingan dan perkembangan dalam sejarah pendidikan di Indonesia. Sebab itu pula, pola kehidupan yang dilakukan, memberikan teladan bagi kita untuk menjaga pentingnya persiapan hidup sekarang dan yang akan datang.

Lembaga pendidikan di Indonesia belum sepenuhnya memiliki lulusan yang relevan dengan kebutuhan pasar tenaga kerja domestik. Terbukti pengangguran tenaga terdidik masih sangat banyak. Harus diakui memang, basic pendidikan di Indonesia disiapkan untuk menjadi tenaga kerja bukan menjadi pembuat kerja atau wirausaha. Tak terkecuali pendidikan yang berbasis vokasi, seperti SMK dan konsentrasi ilmu-ilmu teknik. Pasca lulus mereka sibuk mencari lowongan pekerjaan berbekal nilai yang berkemas ijazah. Ironis memang, Negara yang memiliki sumber daya mineral tinggi terlena dengan kehidupan pragmatis dan hedonis. Akhirnya, Negara asing yang mampu memanfaatkan kekayaan sumber daya alam tersebut.

\section{B. PEMBAHASAN}

\section{Konsep Kewirausahaan Islam}

Berbagai macam definisi kewirauusahaan menurut para ahli yang sudah populer, maka kewirausahaan yang berhasil dikutip adaah sebagai berikut : 
a. Kewirausahaan adalah suatu nilai yang diwujudkan dalam perilaku yang dijadikan sumber daya, tenaga penggerak, tujuan, siasat, kiat proses dan hasil bisnis.

b. Kewirausahaan adalah suatu nilai yang dibutuhkan untuk memulai sebuah usaha dan mengembangkan usaha.

c. Kewirausahaan adalah suatu proses dalam mengerjakan sesuatu yang baru (kreatif) dan berbeda (inovatif) yang bermanfaat dalam memberikan nilai lebih.

d. Kewirausahaan adalah kemempuan untuk menciptakan sesuatu yang baru dan berbeda.

e. Kewirausahaan adalah suatu proses penerapan kreativitas dan keinovasian dalam memecahkan persoalan dan menemukan peluang untuk memperbaiki kehidupan usaha.

f. Kewirausahaan adalah usaha menciptakan nilai tambah dengan jalan mengombinasikan sumber-sumber melalui cara-cara baru dan berbeda. ${ }^{5}$

Berdasarkan definisi yang telah diungkapkan oleh beberapa para ahli mengenai kewirausahaan, dapat ditarik kesimpulan bahwa kewirausahaan merupakan suatu usaha untuk menciptakan dan mengembangkan usaha baru dengan mengelola sumber daya yang ada, dengan menggunakan cara-cara yang kreatif dan inovatif untuk menciptakan suatu hasil yang memiliki nilai manfaat untuk membangun atau memperbaiki perekonomian masyarakat.

Secara umum Allah SWT telah menjelaskan dalam surat Q.S. Al-Qashash ayat 77 yaitu:

${ }^{5}$ Muhammad Yunus, Bisnis Sosial: Sistem Kapitalisme Baru yang memihak kaum Miskin, (Jakarta: Gramedia, 2012), hlm. 31-32. 


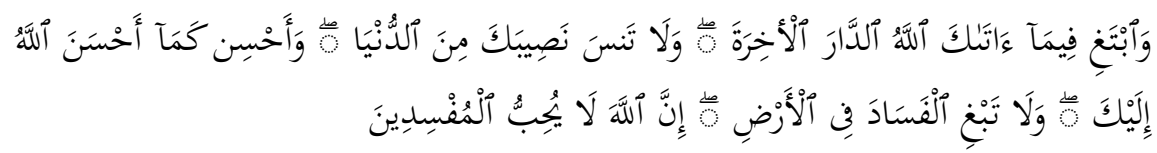

Dan carilah pada apa yang telah dianugerahkan Allah kepadamu (kebahagiaan) negeri akhirat, dan janganlah kamu melupakan bahagianmu dari (kenikmatan) duniawi dan berbuat baiklah (kepada orang lain) sebagaimana Allah telah berbuat baik, kepadamu, dan janganlah kamu berbuat kerusakan di (muka) bumi. Sesungguhnya Allah tidak menyukai orang-orang yang berbuat kerusakan.

Selanjutnya Allah SWT juga menjelaskan dalam surat Q.S AtTaubah Ayat 105:

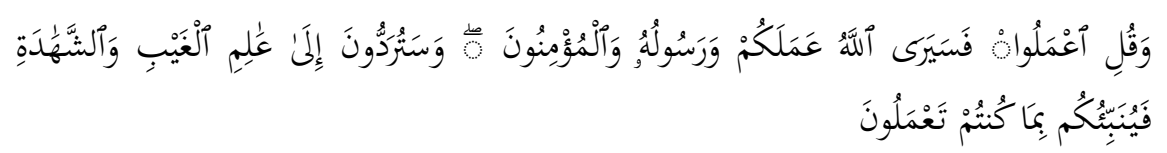

Dan Katakanlah: "Bekerjalah kamu, Maka Allah dan Rasul-Nya serta orang-orang mukmin akan melihat pekerjaanmu itu, dan kamu akan dikembalikan kepada (Allah) yang mengetahui akan yang ghaib dan yang nyata, lalu diberitakan-Nya kepada kamu apa yang telah kamu kerjakan.

Dari kedua ayat tersebut memberikan pemahaman bahwa bekerja atau berwirausaha dengan berlandaskan iman mengandung makna untuk bekerja guna mencukupi kebutuhan hidup dengan senantiasa mengingat dan mengharap ridha Allah SWT dinilai sebagai ibadah. Banyak sekali tuntutan dalam Al-Qur'an dan Hadits yang mendorong seorang muslim untuk bekerja.

Selain itu, Rasulullah SAW juga sangat memberikan penekanan pada kaum muslim, agar giat bekerja dan mempunyai etos kerja yang tinggi. Rasulullah SAW yang mulia dikabarkan mencium tangan sahabat Saad bin Muadz tatkala melihat tangan Saad sangat kasar akibat bekerja keras, seraya berkata, "Kaffani yuhubbuhumallau ta'ala" "inilah dua tangan yang dicintai Allah ta'ala'. 
Bila orang yang giat bekerja dipuji, sebaliknya Islam juga sangat mencela orang malas. Suatu ketika sahabat Umar bin Khattab datang ke masjid diluar waktu shalat lima waktu. Dilihatnya ada dua orang yang terus menerus berdo'a di masjid. Umar menghampiri mereka seraya bertanya "sedang apa kalian, sedangkan orang-orang di sana kini tengah sibuk bekerja?", mereka menjawab, "Yaa Amirul Mu'miniin, sesungguhnya kami adalah orang-orang yang bertawakkal kepada Allah.” Mendengar perkataan itu marahlah Umar "kalian adalah orang-orang yang malas bekerja sedangkan langit tidak akan menurunkan hujan emas dan perak". 6

\section{Kewirausahaan Tionghoa Muslim}

Menurut Geoffrey G. Mendith, kewirausahaan merupakan gambaran dari orang yang memiliki kemampuan melihat dan menilai kesempatan-kesempatan bisnis; mengumpulkan sumber daya yang dibutuhkan untuk mengambil keuntungan dari padanya, serta mengambil tindakan yang tepat guna memastikan kesuksesan. Kewirausahaan senantiasa terkait dengan masa lalu, masa kini, dan masa depan yang juga bertalian dengan imajinasi manusia. Di masamasa itulah, manusia menghadapi hambatan, kesulitan, dan kesenangan secara bercampur baur menjadi satu.

Barang kali inilah argumentasi yang pernah diberikan oleh David Mc Cleland dan Moko P Astamoen (2005) bahwa suatu Negara akan mencapai tingkat kemakmuran apabila jumlah enterpreneurnya paling sedikit $2 \%$ dari jumlah penduduknya. Terlepas dari pernyataan tersebut, tentunya kemakmuran suatu

${ }^{6}$ Ismail Yusanto, Muhammad, dan M. Karebet Widjajakusuma, Menggagas Bisnis Islami, (Jakarta: Gema Insani Press, 2002), hlm. 9. 
bangsa perlu dorongan dari pemerintah untuk meningkatkan dan menghargai kreatifitas penduduknya. ${ }^{7}$

Seperti halnya ilmu manajemen yang awalnya berkembang di bidang industri kemudian berkembang dan diterapkan dalam berbagi bidang lainnya, maka disiplin ilmu kewirausahaan dalam perkembangannya mengalami evolusi yang pesat. Pada mulanya kewirausahaan berkembang dalam perdagangan namun kemudian diterapkan di berbagai bidang lain, seperti industri, perdagangan, pendidikan, kesehatan institusi lain seperti lembaga pemerintah, perguruan tinggi dan lembaga swadaya lainnya. ${ }^{8}$

Sejarah mengakui bahwa Etnis Tionghoa memiliki jiwa entrepreneur yang tinggi. Hai tersebut bermula dengan kepercayaan bahwa tanah itu adalah suci dan didiami ro-roh yang bila dipuaskan akan mendapatkan kemakmuran. Sehingga pada akhirnya orang Tionghoa yang mampu memanfaatkan tanah untuk ditanami akan mendapat berkah dan memiliki hubungan sempurna dengan para dewa. $^{9}$

Nampaknya filosofi inilah yang menjadi pijakan kuat bagi etnis Tionghoa. Di manapun dia berpijak di situ dia akan menjadi penguasa bila mampu memanfaatkan lahan dan kesempatan yang dia miliki. Hal tersebut juga dilakukan KH. Iskandar El Hasani pengasuh pondok pesantren Mutiara Hati Beriman di kota Salatiga. Pasca tahun 1998 usahanya untuk menjadi wirausahawan yang 2008), hlm 9.

${ }^{7}$ Eman Suherman, Desain Pembelajaran Kewirausahaan, (Bandung: Alfabeta,

${ }^{8}$ Suryana, Kewirausahaan; Pedoman Praktis Kiat Dan Sukses Menuju Proses, (Jakarta: Salemba Empat, 2009), hlm.11.

${ }^{9}$ Walter A. Feirservis, Jr, Asal-Asul Peradaban Orang-Orang Jawa Dan Tionghoa, (Surabaya: Selasar, 2009), hlm.158. 
religius terwujud dengan baik. Alumni STAIN Salatiga ini memiliki semangat berwirausaha yang tinggi, Sambil mengajarkan ilmu yang diraih di bangku perkuliahannya, dia juga memiliki bisnis yang cukup sukses.

Dalam kacamata Agama Islam sendiri memang tidak memberikan penjelasan secara eksplisit terkait konsep tentang kewirausahaan (entrepreneurship) ini, namun di antara keduanya mempunyai kaitan yang cukup erat; memiliki ruh atau jiwa yang sangat dekat, meskipun bahasa teknis yang digunakan berbeda. Dalam Islam digunakan istilah kerja keras, kemandirian (biyadihi), dan tidak cengeng. Setidaknya terdapat beberapa ayat al-Qur'an maupun Hadis yang dapat menjadi rujukan pesan tentang semangat kerja keras dan kemandirian ini, seperti; "Amal yang paling baik adalah pekerjaan yang dilakukan dengan cucuran keringatnya sendiri, 'amalurrajuli biyadihi”.

Sejarah Nabi Muhammad, istrinya dan sebagian besar sahabatnya adalah para pedagang dan entrepre mancanegara yang pawai. Beliau adalah praktisi ekonomi dan sosok tauladan bagi umat. Oleh karena itu, sebenarnya tidaklah asing jika dikatakan bahwa mental entrepreneurship inheren dengan jiwa umat Islam itu sendiri. Bukankah Islam adalah agama kaum pedagang, disebarkan ke seluruh dunia setidaknya sampai abad ke $-13 \mathrm{M}$, oleh para pedagang muslim.

Dari aktivitas perdagangan yang dilakukan, Nabi dan sebagian besar sahabat telah merubah pandangan dunia bahwa kemuliaan seseorang bukan terletak pada kebangsawanan darah, tidak pula pada jabatan yang tinggi, atau uang yang banyak, melainkan pada pekerjaan. Oleh karena itu, Nabi juga bersabda "Innallaha yuhibbul 
muhtarif' (sesungguhnya Allah sangat mencintai orang yang bekerja untuk mendapatkan penghasilan). Umar Ibnu Khattab mengatakan sebaliknya bahwa, "Aku benci salah seorang di antara kalian yang tidak mau bekerja yang menyangkut urusan dunia. ${ }^{10}$

Mencari suatu kebenaran yang ada tidak hanya bertumpu pada sebuah titik yang akan berhenti di suatu tempat. Akan tetapi kebenaran itu terjadi ketika realitas itu terjadi. Ketika pendidikan kewirausahaan mampu memberikan solusi dari setumpuk permasalahan perekonomian di Indonesia, maka pola pendidikan tersebut dekat dengan usaha dan semangat tujuan pendidikan.

\section{Konsep Kewirausahaan Tioghoa Muslim}

Berwirausaha berarti melakukan aktivitas kerja keras. Dalam konsep Islam kerja keras haruslah dilandasi dengan keimanan kepada Allah SWT. Bekerja dengan berlandaskan keimanan mengandung makna bahwa bekerja untuk mencukupi kebutuhan hidup dengan senantiasa mengingat dan mengharap Ridha Allah SWT dalam dinilai sebagai ibadah.

Mengenai pengertian dan konsep kewirausahaan, sebetulnya banyak pakar yang telah mengemukakan. Namun kajian definisi kewirausahaan yang telah dikemukakan selalu mengandung unsur kreatifitas, inovasi, dan risiko. Dengan demikian setiap pelaku kewirausahaan atau wirausahawan meiliki nilai lebih dibanding pelaku usaha atau pengusaha biasa. ${ }^{11}$

Banyak sekali tuntutan dalam Al-Qur'an dan Hadits yang mendorong seorang muslim untuk bekerja. Dalam konsep Islam

${ }^{10}$ Subur, Islam Dan Mental Kewirausahaan, Jurnal Insania Fakultas Tarbiyah Stain Purwokerto, (Purwokerto: STAIN press, 2007), hlm. 3-5. 2008), hlm.11.

${ }^{11}$ Eman Suherman, Desain Pembelajaran Kewirausahaan, (Bandung: Alfabeta. 
kegiatan yang berkaitan dengan kewirausahaan harus memiliki beberapa point penting yaitu ${ }^{12}$ :

a. Mencapai target hasil: Profit materi dan Benefit non materi,

Seorang pengusaha Islam membentuk suatu usaha baru dengan tujuan yang tidak hanya mencari profit (Qimah Madhiyah atau nilai materi) setinggi tingginya, tetapi harus juga memperoleh dan memberikan benefit (manfaat) non-materi kepada internal usahanya dan eksternal (lingkungan masyarakat), seperti terciptanya suasana persaudaraan, kepedulian sosial, dan sebagainya. ${ }^{13}$

b. Menegakkan keadilan dan kejujuran,

Keadilan dan kejujuran merupakan hal yang sangat dijunjung dalam Islam yang harus melekat pada diri pengusaha dalam melayani pembelinya. Nabi Muhammad SAW telah memberikan contoh berdagang dengan cara mengutamakan kejujuran keadilan, artinya tidaklah ada bagian dari barang yang dijualnya baik komposisi, kualitas dan harganya yang Ia sembunyikan, dengan sikap kejujuran beliau para pelanggannya pun merasa senang dan puas.

\footnotetext{
${ }^{12}$ Ismail Yusanto, Muhammad, dan M. Karebet Widjajakusuma, Menggagas Bisnis Islami (Jakarta: Gema Insani Press, 2002), hlm 20.

${ }^{13}$ Di dalam konsep ekonomi Islam juga Qimah Insaniyah, Qimah Khuluqiyah dan Qimah Ruhiyah. Dengan orientasi Qimah Insaniyah, berarti pengelola usaha (wirausahawan) juga dapat memberikan manfaat yang bersifat kemanusiaan melalui membuka kesempatan kerja sehingga mengurangi jumlah pengangguran, bantuan sosial (sedekah) sehingga dapat meratakan pendapatan masyarakat. Sementara Qimah Khuluqiyah mengandung pengertian bahwa nilai-nilai akhlaqul karimah menjadi suatu kepastian yang harus muncul dalam setiap aktivitas pengelolaan usaha, misalnya perolehan yang halal dan thayib, bersaing dengan perusahaan atau usaha lain dengan cara yang sehat dan dapat menjalin hubungan ukhuwah baik dengan karyawan maupun dengan mitra bisnis yang lain. Qimah Ruhiyah berarti perbuatan tersebut atau usaha yang dilakukannya dimaksudkan untuk mencari keberkahan dan keridhaan Allah SWT.
} 
Sikap jujur dan adil pada hakikatnya akan melahirkan kepercayaan (trust) dari pihak pelanggan. Rasulullah SAW bersabda: "Pedagang yang jujur lagi terpercaya adalah bersama-sama nabi, orang-orang shiddiqiin, dan para syuhada." (H.R. Tirmidzi dan Ibnu Majjah). Bentuk kejujuran yang dijalankan oleh wirausahawan tionghoa muslim adalah dalam hal pemberian informasi mengenai barang yang dijual, misalnya jika terdapat kerusakan atau penurunan kualitas maka akan disampaikan kepada calon pembeli. Sedangkan keadilan adalah kesiapan mereka untuk memberikan kompensasi dan pengembalian terhadap barang-barang rusak saat dibeli oleh pelanggan, dan masih banyak bentuk-bentuk kejujuran dan keadilan yang lain.

c. Ihsan dan jihad dalam bekerja,

Ihsan dan jihad dalam bekerja, Islam tidak semata-mata memerintah kerja dan berusaha, tetapi juga memerintahkan bekerja dengan profesional dan bersungguh-sungguh. Hendaknya seorang muslim bekerja dengan ketekunan, kesungguhan, konsisten, dan kontinu. Ihsan dalam bekerja bukan perkara sunat, bukan keutamaan, bukan pula urusan sepele dalam pandangan Islam, tetapi suatu kewajiban agama bagi setiap muslim.

d. Prinsip kehati-hatian.

Prinsip Kehati-hatian di dalam konsep ekonomi Islam terbagi dalam beberapa hal yaitu:

1) Hati-hati dalam Bersumpah

Hal ini sesuai dengan pesan Rasulullah SAW: "Jauhilah oleh kalian sетиa sumpah-sumpah dalam berdagang, 
karena ia akan membuat laris dagangan, tetapi akan menghilangkan keberkahan laba."

2) Hati-hati dalam Berpromosi

Tidak hanya itu, Rasulullah SAW juga berpesan: "Meyakinkan pembeli dengan berbohong adalah haram" (H.R. Ath-Thabrani).

\section{Penutup}

Kewirausahaan merupakan suatu usaha bagi manusia yang dituntut untuk dapat membuka suatu kegiatan yang dapat memunculkan suatu dampak positif bagi perkembangan perekonomian. Dengan adanya kewirausahaan seseorang dapat berperan sebagai pengurang angka pengangguran dengan membuka lapangan pekerjaan. Terebih dalam hal ini Allah sendiri dalam firman-firmannya dan melalui rasulnya memberikan pemahaman akan pentingnya seorang hamba yang berusaha dan bekerja untuk memenuhi kebutuhannya.

. Konsep kewirausahaan ini telah ada dan dijunjung tinggi oleh agama Islam, karena wirausaha dalam Islam memiliki banyak fungsi, fungsi tersebut dapat berdampak positif baik bagi dirinya, keluarganya, masyarakat, dan seluruh alam semesta. Etnis Tionghoa telah memberikan bukti konkret di negara Indonesia keberhasilan dalam berwirausaha. Jika usaha itu dikelola dengan menaati hal-hal yang diperintahkan oleh ajaran Islam dan tidak menimbulkan kerusakan di muka bumi, maka kewirausahaan yang baik menurut agama Islam dapat menumbuhkan kemaslahatan baik di dunia maupun di akhirat kelak. 
Jurnal Pendidikan Agama Islam Universitas Wahid Hasyim Semarang

\section{DAFTAR PUSTAKA}

Eman Suherman, Desain Pembelajaran Kewirausahaan, Bandung: Alfabeta. 2008.

I.wibowo dan Thung Ju Lan, Setelah Air Mata Kering; Masyarakt Tiong Hoa Pasca Mei 1998, Jakarta: Kompas. 2010.

Ismail Yusanto, Muhammad, dan M. Karebet Widjajakusuma, Menggagas Bisnis Islami, Jakarta: Gema Insani Press, 2002.

Kasmir, Kewirausahaan, Jakarta; PT Raja Grafindo Persada, 2009.

Qaradhawi, Yusuf, Daurul Qiyam wal Akhlaq fil Iqtishadil Islami, Kairo: Maktabah Wahbah, 1995.

Shihab, Quraish, Tafsir Al-Mishbah: Vol. 10, Jakarta: Lentera Hati, 2002.

Suara merdeka, Islam-China Di Pesantren Mutiara, Semarang: Suara Merdeka 19 Februari, 2012.

Subur, Islam Dan Mental Kewirausahaan, Jurnal Insania, Purwokerto: STAIN press, 2007.

Suryana, Kewirausahaan; Pedoman Praktis Kiat Dan Sukses Menuju Proses, Jakarta; Salemba Empat, 2009.

Tan Ta Sen, Cheng Ho, Penyebar Islam dari China ke Nusantara, Jakarta: Kompas, 2010.

Yuanzhi kong, cheng ho; muslim tionghoa, Jakarta; Yayasan Pustaka Obar Indonesia, 2011.

Muhammad Yunus, Bisnis Sosial; Sistem Kapitalisme Baru yang memihak kaum Miskin, Jakarta: Gramedia, 2012.

Walter A. Feirservis, Jr, Asal-Asul Peradaban Orang-Orang Jawa Dan Tionghoa, Surabaya: Selasar, 2009. 